Case for Teaching

\title{
"Not One Less"! Adaptation to the Home Office in Times of COVID-19
}

\section{"Nenhum a Menos"! A Adaptação ao Home Office em Tempos de COVID-19}

Discipline: People Management Subject: Home Office, Adaptation Industry: Technology, Management Systems

Geography: Paraíba/Brazil
Thaís Lopes de Lucena Alves ${ }^{10}$ Amanda Florense Alves Amorim ${ }^{10}$ Maria Clara Cunha Bezerra' ${ }^{10}$

\section{STARTING...}

"Not one less!" said Carlo, CEO of Chianca Softwares, referring to keep all the employees in his company during the COVID-19 pandemic as it has caused financial difficulties for organizations all over the world. Some organizations dismissed much of their staff and had to reinvent themselves, while many others fatally closed down.

In 2020, Chianca Softwares was located in the city of João Pessoa, in the state of Paraíba. As Carlo Chianca had decided not to lay off any of his 50 employees, Danielle Chianca, director of human resources and business management, had the mission of implementing a new work

1. Universidade Federal da Paraíba, Centro de Ciências Sociais Aplicadas, Programa de Pós-Graduação em Administração, João Pessoa, PB, Brazil.

Cite as: Alves, T. L. de L., Amorim, A. F. A., \& Bezerra, M. C. C. (2021). "Not one less"! Adaptation to the home office in times of COVID-19. Revista de Administração Contemporânea, 25(spe), e200234 https://doi.org/10.1590/1982-7849rac2021200234.en system that would allow the continuity of the engagement and unity of the entire team.

The manager accepted the challenge and developed a new remote work modality on an emergency basis, by implementing management practices and engagement in home office modality. However, after this work modality had been implemented, the Decree No. 40,304 of the state of Paraíba issued a return to workplace plan and Carlo found himself in a dilemma: Should Chianca restore its original patterns back to in-person work modality or should maintain in home office?
JEL Code: A20, J81, H12.

Editor-in-chief: Wesley Mendes-Da-Silva (Fundação Getulio Vargas, EAESP, Brazil) (1) Associate Editor: Paula C. P. de S. Chimenti (Universidade Federal do Rio de Janeiro, COPPEAD, Brazil) Guest Editor: Leonardo Marques (Universidade Federal do Rio de Janeiro, COPPEAD, Brazill) Reviewers: Samuel Façanha Câmara (Universidade Estadual do Ceará, PPGA, Brazil) (t) Alice Monnerat Erthal Levi (Universidade Federal do Rio de Janeiro, COPPEAD, Brazil) Peer Review Report: The Peer Review Report is available at this external link.

\begin{tabular}{|c|c|c|c|c|c|c|c|c|c|}
\hline & 1 & 2 & 3 & 4 & 5 & 6 & 7 & 8 & 9 \\
\hline $1^{\text {st }}$ round & & $\stackrel{9}{2}$ & & & & & & & \\
\hline $2^{\text {nd }}$ round & & & & & & & & & \\
\hline $3^{\text {rd }}$ round & & & & & & & & & \\
\hline
\end{tabular}




\section{DA DA DUM! A THREAT HAS BEEN DETECTED!}

It all started with the pandemic caused by the new coronavirus, SARS-CoV-2 outbreak, which started in Wuhan, China, in December 2019 and quickly spread worldwide. It arrived in Brazil on February 26, 2020, when the first confirmed case of contamination was registered. Since then, the new coronavirus has interfered in the various agendas of the country, having impact not only on health system but also on the economy.

Such scenario worried Carlo Chianca, so, on the night of March 14, 2020, after noticing that the main topic on newspapers was this global pandemic, Carlo promptly called Danielle Chianca, his daughter and head of the company, and commented on the situation: "Hello, daughter. Are you fine? Did you see the newspaper today? As you may already know, we are facing a pandemic that may severely impact our company. Yesterday the Decree No 40,135 of March 13, 2020 was issued with a number of temporary and emergency measures of prevention referring to COVID-19 that we must follow.”

Danielle, who had just arrived from the company and was watching the news, related to Carlo's apprehension: "Hi, dad, I did, and I'm very worried! Today I read a report that in March it will be already possible to feel the effects of the pandemic on the job market with regard to unemployment rates. In the news report, FGV economist Rodolpho Tobler says that 'This was the second biggest fall in the historical series, behind only the one that occurred in the 2008-09 crisis. The negative scenario should persist in the coming months, considering the growing increase in uncertainty in the country."”

That was a long night for Carlo and Danielle who, after an hour and a half on phone call, kept thinking about the uncertainties and difficulties that their company would have to face from there.

\section{LOADING 50\%... - KNOWING THE HISTORY OF CHIANCA SOFTWARES}

Chianca Softwares (Figure A1 - Appendix A), a medium-sized family business in the state of Paraíba, was born out of the dream of Carlo Chianca, a former bank employee who ventured into developing management solutions for companies. What seemed like a distant dream came true when Carlo developed his first system and sold it to his first customer in 1992.
At the beginning, the company, then called Enter Informática, had a very small team that had various functions. However, over time, their operations became more specific and not only did the team needed to be reinforced by hiring more employees, but also the company name was changed to Chianca Softwares.

Chianca Softwares consolidated itself in 2003 in the information technology industry and services, operating in the creation of software for business management in the industry segment, services, retail, and wholesale. Thus, the company commercialized sales prospecting systems, inventory tracking, outside sales, electronic guest check, integrated accounting system, as well as integration and implementation of e-commerce, delivery platform, and satisfaction survey panel.

Its diversified market served companies from various sectors such as supermarkets, furniture stores, auto parts, building materials, pet shops, distribution companies, fashion, optical shops, restaurants, and beauty salons. Its services included Greater João Pessoa areas as Santa Rita, Bayeux, and Cabedelo and the states of Pernambuco and Rio Grande do Norte.

The company annually carried out its strategic planning and had standard guidelines. Its mission was 'to accelerate business with autonomous management, empowering people for the future.' This vision was described as 'be the ideal solution for companies aiming to enhance their management and be among the top ten players of technology and innovation for the enterprise market by 2022.' Regarding the values: 'make it happen together, focus on results, innovation, ethics, quality, and human development.'

From a changing process in its governance model, which occurred in 2012, the company started to adopt improvements in its internal and control processes, which increased its capacity for innovation and management practices. This new positioning took the company to the end of the state stage of MPE Brasil Award given by Sebrae PB in 2014, when it participated in the award for the first time. In 2015, this improvement continued through the training of the team and the focus on innovative actions, which led Chianca Softwares to win the state stage of the MPE-PB Award in the Information Technology Services category. 


\section{LOADING... 100\% - KNOWING CHIANCA SOFTWARES MANAGEMENT}

The company culture in 2020 was extremely lively and adaptive. Danielle Chianca has always been an active participant in the activities by promoting various integration and engagement actions. The company had a well-defined visual identity in its physical structure with its logo in all its artefacts, from mouse pad, intranet, equipment, cars decorated with the company's logo sticks, to the walls of the company, which were painted with slogans, strategic guidance, and messages to inspire the employees about their mission.

There was a break room at Chianca Softwares, with sofas and a coffee corner, as well as a game room for entertainment moments with the team. There was also a lounge for pitches (quick meetings), one-on-one meetings (meetings between two people to give feedback) and coworking (collaborative workspace). In addition, the company has been restructured over the years and has implemented a solar panel system, thus contributing to environmental responsibility practices.

Processes regarding personnel management at Chianca were based on aggregating, applying, developing, maintaining, and monitoring practices. Regarding aggregating practices, Chianca followed traditional requirements with recruitment, selection, and socialization. As for the application process, the new employee allocated in his specific area was evaluated for a period of experience. In socialization, circles of conversation were held on company matters of interest so that the new employee could adhere to the company culture and its management practices. The performance of employees was constantly assessed through daily and weekly targets, depending on the sector, and monitored by their leaders, who were encouraged to give feedback on results.

Regarding the process of developing people, the company provided and fomented personal development by distributing books, providing online courses, and promoting lectures on topics such as leadership and emotional intelligence. Training was indicated by the leaders based on the needs observed in each team and sometimes carried out by the employees themselves, permeating organizational knowledge. In addition, the company developed a communication channel called News Chianca, which facilitated internal communication to share events, Birthday Boy/Girl of the Month, new projects, and management practices.

Among the practices for keeping people, several activities of mobilization and integration of personnel, quality of life, and social responsibility have been applied in recent years. As for the company's integration projects, the Day of Gratitude was implemented (Figure A2 - Appendix A), in which each member would choose another member to send messages of gratitude during the month. These messages were posted on a shared wall so that everyone could see them.

Another practice adopted was the Birthday Boy/ Girl of the Month, in which, at the end of each month, the company sponsored a thematic coffee break and celebrated with the birthday boys/girls. Every two weeks, there was also a happy hour in the company (after 6 pm, i.e., after closing time) and most employees would stay in the company, being a moment of great integration where people would sing and have a good time.

Regarding the quality of life and social responsibility projects, Chianca Fit and Day $\mathrm{C}$ were implemented. Chianca Fit (Figure A3 - Appendix A) aimed to encourage employees to practice physical activities, in order to improve their health and well-being. If the monthly target of 720 points/minutes per employee was reached, the company would donate 100 kilos of food to some charity institution. The Day C (Figure A4 - Appendix A), in turn, was a project in which the employees would visit an institution and promote the integration and socialization.

Regarding processes to monitor people, these were anchored in day-to-day management practices. Leaders would play a direct role in monitoring the goals and results of the team in the sector in which they worked. There was a clock-in clock-out electronic system in the company and absences, leave, and holidays were monitored by personnel and management sector. As for information security, the employees were oriented to the restricted use of applications and cell phones during working hours, besides following the safety rules about the information handled in the company.

\section{PENDING UPDATES: ‘CHIANKERS, LET’S ACT?!'}

After the Decree No 40,135 of March 13, 2020, Chianca Softwares continued its activities, following all the preventive measures for COVID-19, such as the use of alcohol gel distributed in all company rooms, cleaning and disinfection of materials, equipment, and rooms, and the mandatory use of a facemask by all employees. However, it did not take long for an employee to show symptoms of the virus, such as cough and fever, being this employee immediately released from in-person work activities at the company for a period of 15 days. Then, he started to perform his activities in a remote modality to prevent other employees from being infected, which was ensured through a labor agreement for such cases. 
But it did not stop there... The number of cases of people infected with COVID-19 continued to increase in the country and a new decree was issued, leading Carlo to call, to March 19, a meeting on emergency basis with the company's board to address the measures that needed to be taken.

"Chiankers, let's act?!" This was the motto of Chianca to mobilize its team to fulfill its daily goals and innovative projects. It was exactly that phrase that Carlo used to start the meeting: "Good afternoon, Chiankers, let's act? I gathered you here due to the Decree No 9,461 of March 19, 2020 issued today by João Pessoa city government, suspending public transport, which, in turn, will make it impossible for most of our employees to commute."

His son, Junior (Head of Marketing), was the first to address the issue: "More decrees! What's next? What about the employees? How can we solve this problem of the lack of public transport, since about $70 \%$ of our employees depend on it?"

Danielle, attentive to the latest news, had an idea: "I know! We can create a route from the employees' homes to the nearest areas and use the company's cars so that those who know how to drive can pick and leave the other employees in their area."

Junior, however, pointed out some issues: "Great idea, Danielle! It would be a good way out. However, this will cause high costs with fuel if every day we have to leave and pick 50 employees, not considering the commute time for all these routes, besides being a deviation of agreed position for the employees who would be the 'drivers' of the round. However, we can try it...”

\section{NOT ONE LESS!}

The situation of Chianca Softwares was increasingly critical and, despite trying to remain optimistic, the fact is that Carlo was very concerned about the future of his company. And, as if that were not enough, the day after the meeting, while Carlo was having his coffee and reading the first news of his newspaper, he saw the Decree No 40,135 of March 20, 2020, which had as the main purpose to further restrict business activities, limiting what would and would not work during the quarantine, a period of social confinement.

Racing heart, sweating and uneasy, Carlo walked from one side to the other in his kitchen, wondering what could be a viable solution for him to keep the Chianca Softwares working with not one less. That was the concern that could not get out of the CEO's mind in those turbulent days of uncertainty.
"Breathe and think!" That's what Carlo said to himself. Then, while he was driving to the company, Carlo thought of something that could be an emergency solution to the problems faced, promptly going to Danielle's office: "Good morning, Danielle! Did you see the new Decree No 40,135 of March 20, 2020?" Danielle, who was reading the news on a site, welcomed her father: "Good morning. I've just read. What will we do?" Carlo, then, prepared himself to share his proposal with her: "At first, I worried, but on the way here I believe I had a good idea. I was thinking..."

Before concluding his train of thought, Junior Chianca suddenly entered the room and unburdened himself, recounting the initial consequences of the recent events: "Good morning. I'm glad I found both of you here. You are already aware of the new Decree, aren't you? As if it weren't enough, I've just heard from the customer service department that we are already receiving several order cancellation calls. In fact, the sales sector reported that we are already seeing a reduction in our revenue, because inevitably our customers were directly affected by all these measures." Danielle, worried, asked about what to do: "How are we going to position ourselves in this scenario? We have customers and employees to provide for!"

Carlo, in this apprehensive moment, tried to calm the spirits and, finally, presented his idea: "Let's try to keep calm, guys! If life gives you lemons, make a lemonade. Think with me, despite the pandemic and all its consequences are hitting us, circulation reduction of movement of people in commercial areas is causing an increase in purchases by delivery. Therefore, we will contact all of our customers and offer the delivery platform free, assisting in whatever is necessary in the adaptation process and, thus, we will retain them."

Carlo continued... "In addition, the good news is that it is on the news that the Federal Government issued a provisional measure to keep employees' jobs by suspending work and reducing the workload. Danielle, see how this measure works, because I intend our company to follow the motto: 'Not one less!'”

Danielle, who had already consulted the legal and accounting sector that morning, added: "Good thinking! I learned that the Provisional Measure No 936 comprises the Emergency Employment Benefit Preservation and Income; proportional reduction in working hours and wages; and the temporary suspension of the employment contract paid by the government."

Carlo, seeing a light at the end of the tunnel, and more calm, said: "There! Let's go ahead! Make a survey of how we can adapt the decree for the benefit of all. By the way, Junior, before you had arrived, I was just telling Danielle that I had an idea: Since we are a technology company and most of our 
activities take place in the virtual environment, we can create a remote work modality for all the employees. It would be a great challenge to implement this work modality! Danielle and Junior, what do you think?"

While Junior was thoughtful, Danielle promptly replied: "Yes! We can implement home office system! I will meet with the personnel and management sector and find solutions to implement this new work modality."

The meeting ended with Danielle saying: "You can leave it to me. Let's act?!"

\section{RECONFIGURING THE SYSTEM - IMPLEMENTING HOME OFFICE}

On that same day, March 20, 2020, Danielle Chianca immediately gathered the People and Management team and started to discuss the implementation process of the new remote working arrangements.

Then, when presenting the new proposal for reconfiguring the work system to the team, Isabella, one of her assistants, asked: "Do the employees have structure at home to work? Table, chair, stable internet?"

Eduardo added: "Will people who never worked in home office be able to adapt easily? What about controlling the working hours, how is it going to be?"

Danielle took notes while deliberating with the Personnel and Management team, and, meanwhile, everyone researched about the implementation of home office modality. Thus, they listed some points that needed to be developed: (a) infrastructure of the employees' home office; (b) employees work plan; (c) time control and operation of the company; and (d) conduct manual.

Implementing home office modality was already a challenge and became even greater when it had to be considered on an emergency basis. However, the team did not lose heart and went on to build the plan. For this, the People and Management department contacted the leaders of the sectors to be able to apply it.

In the item about infrastructure, the leaders were responsible for giving support to their subordinates in the construction of the home workspace of each employee and they could distribute the equipment of the company such as table, chair, computer, cell phone, and headset. Each employee should take responsibility for the equipment in his/her custody and, in the event of damage, he/she would pay for the damaged equipment.

For the criterion on time control and operation of the company, it was used the application Ponto Secullum, so that the employee would log in and out of the application at the same times as the in-person work modality.

Regarding the work plan, each leader would also be responsible for holding weekly meetings with a clear description of the deliveries to be made by the sector and every day, at the beginning and at the end of the working day, a meeting would be held to point out the difficulties and what was or was not concluded.

For the conduct manual ${ }^{1}$, the Personnel and Management department created a manual of how the employee should proceed during the work hours, making it clear the expectations of the organization and guiding employees about the dress code, access to the system, communication, workspace, and interaction with family members during office hours.

\section{RECONFIGURED SYSTEM: EXPERIENCING HOME OFFICE}

Despite the challenge, finally, on March 23, the Chiankers began to experience the home office work modality (Figure A5 - Appendix A) and all employees received a manual to follow, which was developed by the Personnel and Management team, led by Danielle Chianca.

In the first week that followed, Carlo and his entire management team were satisfied with the new implementations, as not only they perceived a strong impact in reducing costs with transportation and energy vouchers, but also they received positive feedbacks from some employees who were satisfied to be able to enjoy more time with their families and to reduce their personal expenses with food and commute.

However, after fifteen days of home office, Danielle Chianca got a call from Eduardo informing her that the computer provided by the company had burned out. While the head of Personnel and Management tried to contact the technical support, her phone rang and it was Carlo: "Danielle, we need to review the system for controlling the productivity of the teams because I am feeling that the meetings before and after working hours may be overwhelming the employees. And we need to set up a meeting with the information system manager to protect our data."

Danielle, agreeing, added: "It's true, father. I had the same perception. In addition, I need to send the technical support team to check the operation of the technical equipment made available to employees. I've just received the news of a burned out computer."

When the conversation ended, Danielle started a research process among employees in order to improve 
the new remote work modality. Thus, despite Chianca's effective planning for the infrastructure of the home office system, some of the employees presented complaints, such as: absence of the company's physical structure, fatigue from spending more time in front of the screen, domestic demands, lack of leadership and the feeling of belonging to the culture, and, almost unanimously, the lack of social interaction, moments of relaxation, and the increased perception of organizational isolation. After all, the culture of the organization had always been lively and constant, with the promotion of various integration and engagement actions among employees.

Therefore, Danielle, together with the company's board of directors, sought to adapt the practices of social interaction to the remote pattern. For example, the Gratitude Day action meant that each employee had a hidden friend to share messages of affection during the home office period. Regarding Birthday Boy/Girl of the Month, the company started sending a birthday kit with cake, snacks, and soda to the home of the birthday boy/girl employee. The happy hour practice continued through an online meeting with karaoke, allowing employees to sing and have fun at home.

Chianca Fit was encouraged by a new weekly control template (Figure A6 - Appendix A) that could be published on social networks, influencing not only employees, but the people who were part of their social networks, besides providing greater visibility of the company's brand. Targets and scoring continued to be achieved. Day $\mathrm{C}$ also continued (Figure A7 - Appendix A), with the delivery of an e-book with messages from employees and a collective snack for health professionals at Hospital de Emergência e Trauma Senador Humberto Lucena, thanking for the work of these professionals who were on the front line in the pandemic.

Chianca also decided to mobilize to generate content to teach companies how to adapt in that period. Thus, Chianca became active in digital platforms like Instagram and its site has become a benchmark in communicating innovative and adaptive practices in crisis. In addition, the company held several lives to help and retain its old customers, as well as prospect new ones.

However, it did not stop there... With the extension of the period of quarantine by Decrees No 9,481 of May 1, 2020 and No 40,289 of May 30, 2020 to June 14, 2020, the company has reinvented itself and created other prospects during the crisis. Therefore, because of greater productivity via home office, the company developed two innovations to leverage its customers' businesses, which were the online store and the payment link. The online shop gave unlimited access to visits and products, integrated into the management system, while the link payment enabled the company to send the link with registered purchase information and the customer could pay by credit card.

Thus, Chianca was able to balance its finances with the development of new products, retaining the majority of its customers and joining new customers to its portfolio.

\section{“WHAT'S NEXT, CHIANKERS?" SHOULD WE RESTORE ORIGINAL PATTERNS?}

After three months in home office modality, Carlo, seeing the company working satisfactorily, breathed more easily, especially because he managed to keep his motto of "Not one Less."

At that time, the CEO of Chianca was excited about the new way of working. After all, he managed to get the survival of the business and the retaining of all its employees, with the loss of some customers and getting new ones. However, on June 12, 2020, one more decree was issued by the government of Paraíba, No 40,304, about the adoption of a gradual return to work plan for all activities that had been discontinued since the beginning of the pandemic.

Soon, Carlo once again found himself thoughtful: "The fact is that the lifestyle and consumption style of people have also changed, they have started to live what they are calling 'new normal', but nothing will be as before."

Given this scenario, Carlo spent the rest of the day involved in the following dilemma: Should Chianca restore its original patterns back to the in-person working modality, or maintain the home office modality?

\section{NOTE}

1. Access to the Chianca Softwares Manual. Retrieved from: https://api.chianca.com.br/storage/app/media/manual $\% 20$ home\%20office.pdf 


\section{APPENDIX A. TEACHING CASE IMAGES}

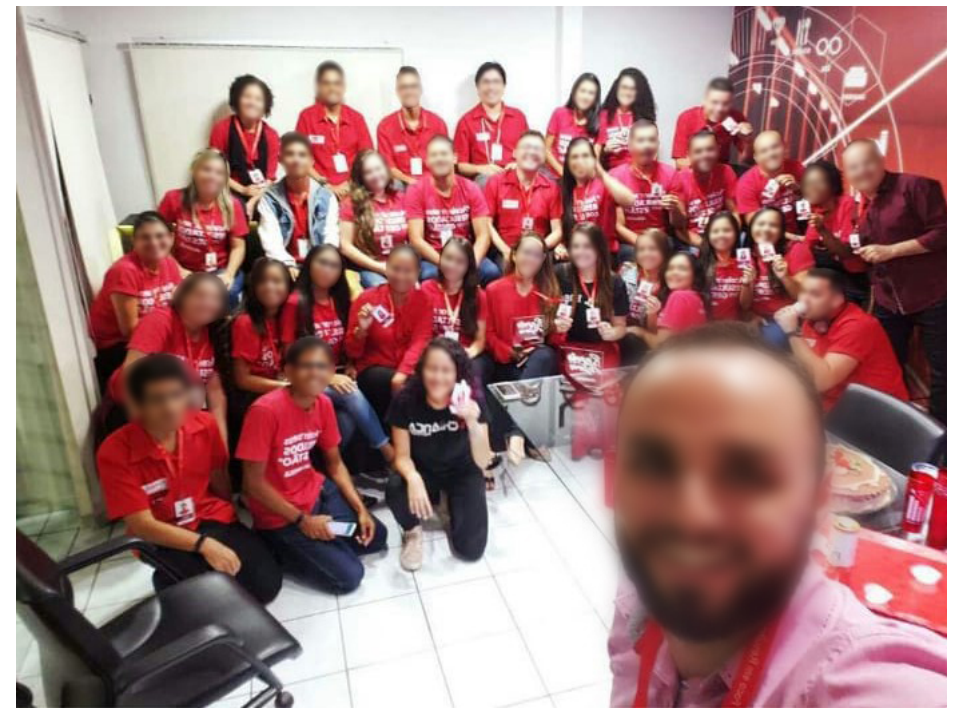

Figure A1. Chianca Softwares team .

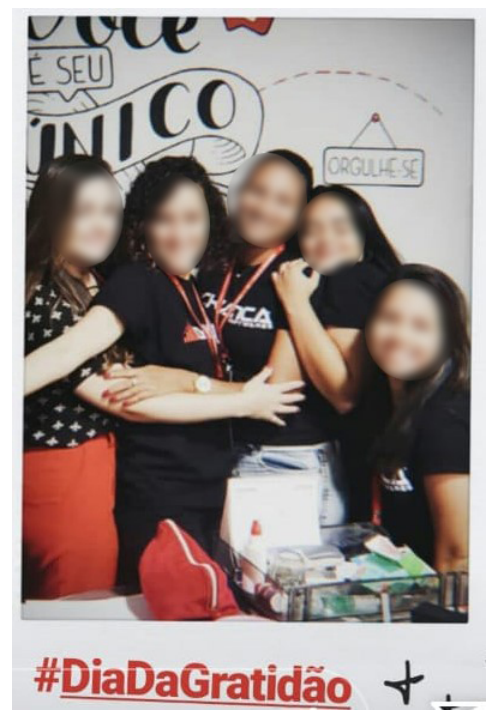

Figure A2. Gratitude Day.

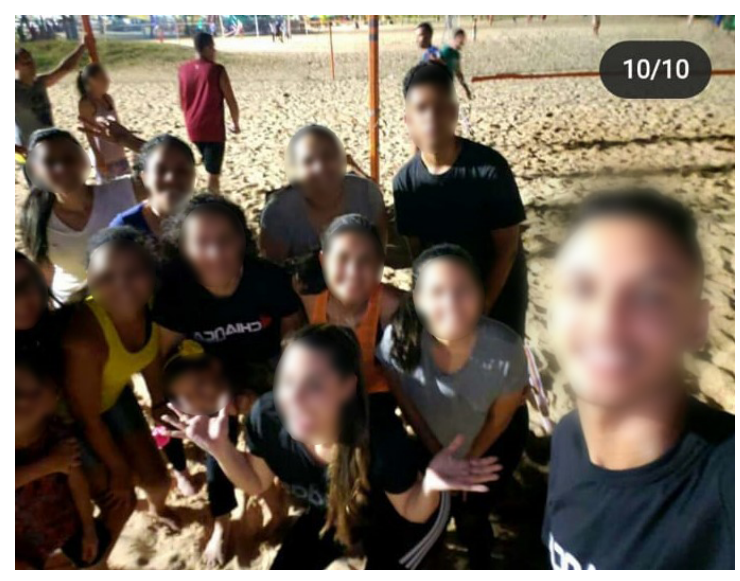

Figure A3. Chianca Fit.

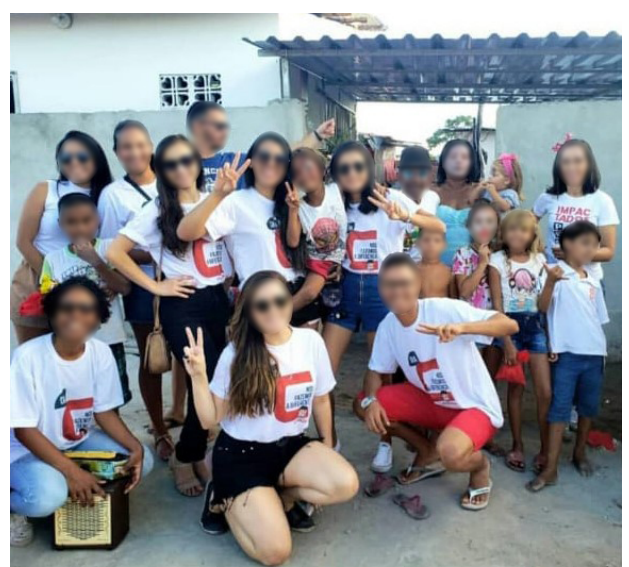

Figure A4. Day C. 


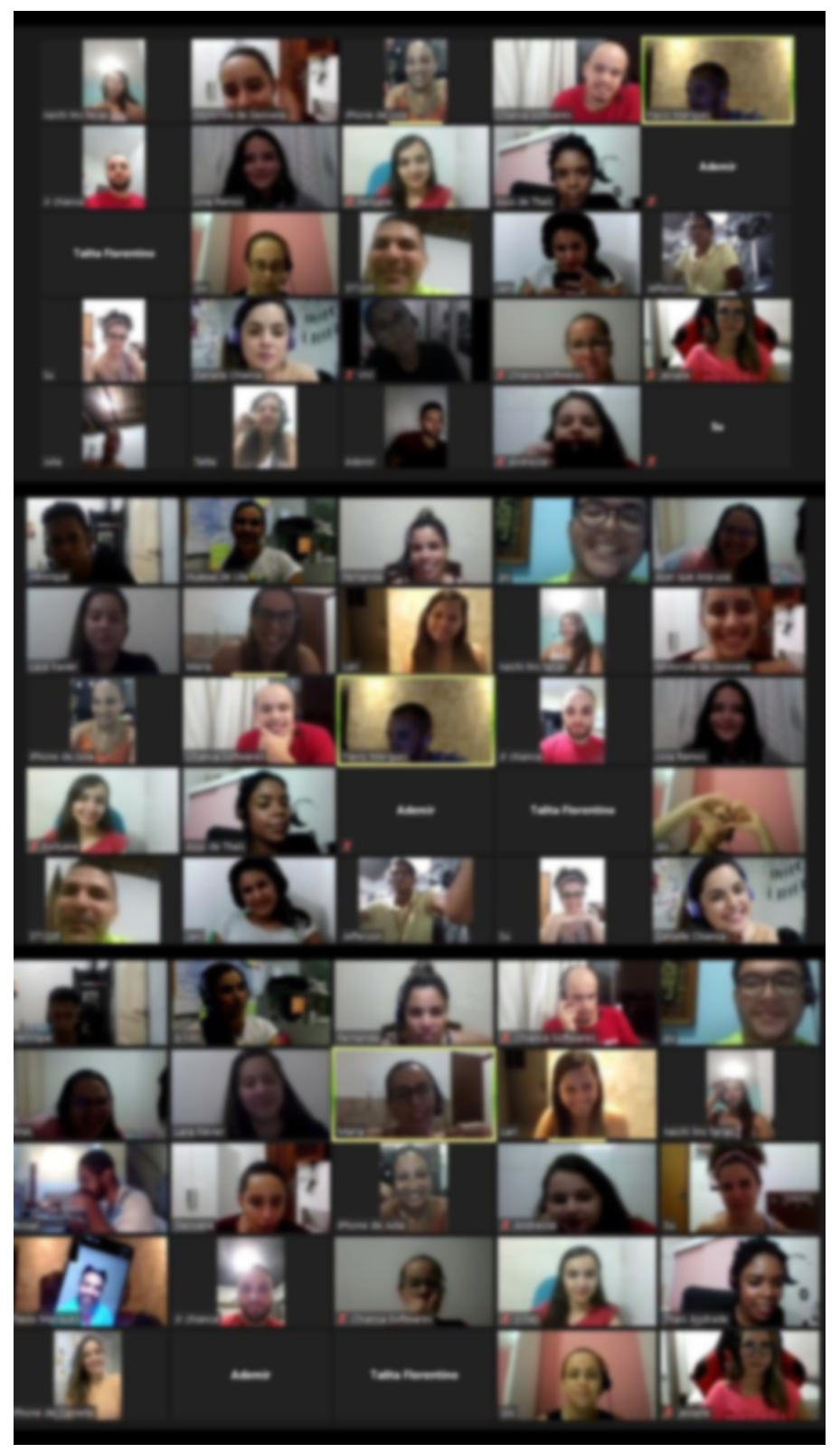

Figure A5. Home office meeting.

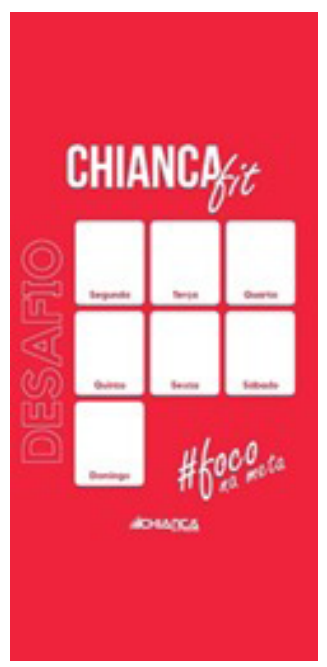

Figure A6. Chianca Fit adaptation.

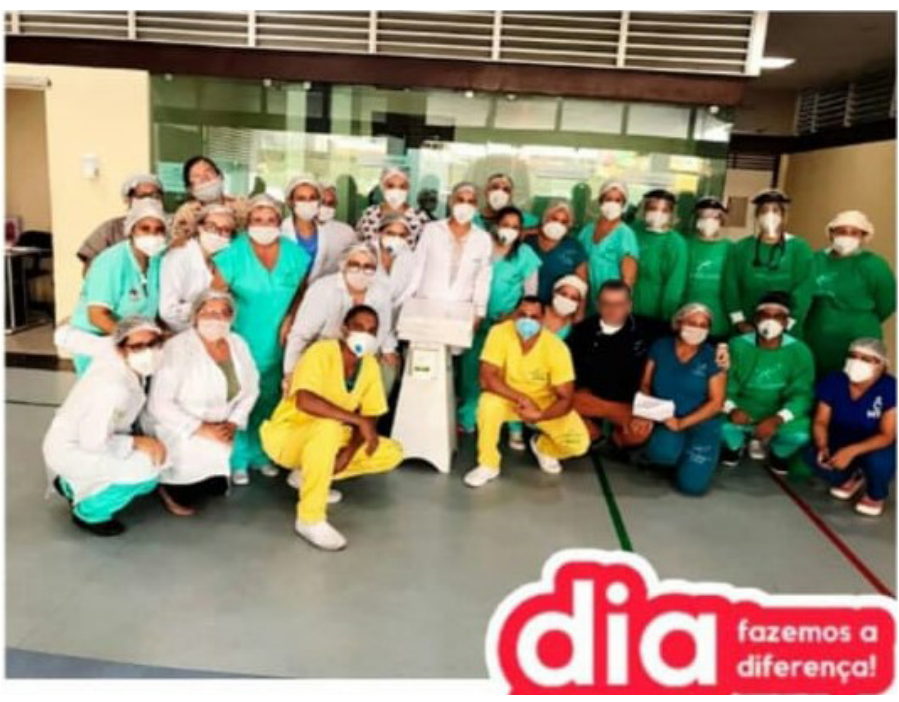

Figure A7. Day C adaptation. 


\section{ABSTRACT}

This case describes the process of changing Chianca Softwares' face-to-face work regime to the home office during government decrees caused by the new coronavirus pandemic. Chianca Softwares, a family company, which has been a player in the technology market in the state of Paraíba since 2003, went through a process of change in its governance model in 2012, and due to the improvements in its processes, it was awarded the Prêmio Média e Pequenas Empresas (MPE) of Sebrae PB in 2016. Given its adaptability, it faced the coronavirus crisis differently, overcame difficulties, and needed to reinvent itself to survive the 'new normal.' In this context, the case aims to lead students to reflect on the home office implementation process in Chianca, to identify the benefits and challenges of this teleworking regime and to think about ways to mitigate these challenges and create tools and practices to mobilize, integrate, and engage people in remote work. Thus, after restructuring its entire team to the new model of work in the home office, students are led to reflect on the dilemma that Chianca managers face due to the release of their face-to-face activities: stay in the home office regime or return to original patterns.

Keywords: teaching case; home office; telework; coronavirus; engagement.

\section{POSITIONING}

It is recommended to apply the case in the undergraduate course in Business Administration and in lato sensu post-graduate in-class or online courses in Personnel Management, Human Resources Management, and Organizational Development. Instead of writing the best teleworking practices, the case aims to analyze the business, social, and economic context in the pandemic period of the new coronavirus and to lead students to reflect on the available ways of implementing teleworking, as well as its advantages and challenges. Topics such as teleworking arrangements, home office, personnel engagement, and organizational culture can be explored.

\section{DATA SOURCES AND COLLECTING METHOD}

The data sources were as diverse as possible because it is a new political, economic, and social context. Some situations were fictitious to illustrate with examples and to give more emphasis on some specific themes of the case.

\section{RESUMO}

Este caso descreveu o processo de mudança de regime de trabalho presencial da Chianca Softwares para o home office durante os decretos governamentais causados pela pandemia do novo coronavírus. A Chianca Softwares, empresa familiar, que atuava como player no mercado de tecnologia no estado da Paraíba desde 2003, passou por processo de mudança em seu modelo de governança em 2012 e, devido às melhorias dos seus processos, foi contemplada com o Prêmio Média e Pequenas Empresas (MPE) do Sebrae PB em 2016. Diante de sua característica de adaptabilidade, enfrentou a crise do coronavírus de forma distinta, superou dificuldades e precisou se reinventar para sobreviver ao 'novo normal'. Nesse contexto, o caso tem por objetivo conduzir os alunos a refletir sobre o processo de implementaçáo de home office na Chianca, identificando quais os benefícios e desafios desse regime de teletrabalho e pensando sobre formas de mitigar esses desafios e de criar ferramentas e práticas para mobilizar, integrar e engajar as pessoas no trabalho remoto. Assim, após reestruturação de todo seu time para o novo modelo de trabalho em home office, os alunos poderão ser levados a refletir sobre o dilema que os gestores da Chianca enfrentaram devido à liberação de suas atividades presenciais: permanecer em home office ou retornar às configuraçóes originais.

Palavras-chave: caso para ensino; trabalho remoto; teletrabalho; coronavírus; engajamento.
The primary sources were based on interviews, informal conversations, and emails exchanges with the real business case.

Secondary sources were the website (http://chianca. com.br/ retrieved in June 12, 2020), the spreadsheet of the Personnel and Management department, and Chianca's social networks during the period of elaboration of the case, as well as websites and newspapers specialized in Personnel Management and the coronavirus, and participation in lives held by the company and by specialists in the area of Personnel Management. It was also possible to take an online course at Sólides RH on 'Team management in home office' that provided the basis for the idea and construction of the case. We also looked for theoretical and empirical research using the keywords: home office, telework, engagement, and COVID-19 in Business Administration literature. 


\section{LEARNING OBJECTIVES}

The case aims to develop in students experiential reflections of a real situation about the change from inperson working arrangements in a technology company to home office modality, as well as address the importance of analyzing this work model that has expanded in Brazil and all over the world and lead the students to think about new teleworking perspectives. Therefore, the following skills and attitudes to be developed through the discussion were listed:

(a) Ability to analyze and comment on the literature, based on evidence presented in the case or experienced by the participants related to the home office implementation process by companies that have undergone adaptability in times of crisis, or those that have developed this remote work system to meet the new demands of social and economic context;

(b) Critical ability to identify and contrast the benefits and challenges inherent to the home office work modality for both companies and employees, taking into account individual, work, technological, organizational, environmental, strategic, and family/domestic aspects;

(c) Ability to reflect on possibilities for mitigating these challenges with new practices for integrating and engaging people and organizational culture in the home office;

(d) Ability to analyze problems and question solutions, as well as listen to different opinions and develop the ability to create arguments and defend them during the interaction in the discussion on viable teleworking modalities, analyzing the case of Chianca Softwares.

\section{ANALYSIS OF THE CASE AND QUESTIONS FOR DISCUSSION}

Based on the case of Chianca Softwares, the students can simulate or relate to the experienced situation and perceive positive and negative factors experienced in the working environment of the home office, as well as discuss how the companies prepare for situations of health, economic, and social crises. In this session, theoretical guiding aspects were addressed to conduct what will be taught with the case through the proposed questions.

The teacher can follow the suggested order of questions: (a) How home office implementation process happens; (b) Identification of the benefits and challenges of the home office for employees and the company; (c) Mitigation of the challenges in the home office; (d) After the discussion of the theoretical aspects and analysis of Chianca Softwares practices, the students must reflect on the context during the pandemic and to assume the position of the company managers to make a decision about which direction to take from the new governmental and organizational measures, as well as to think about other ways to deal with the situation, allowing the student to explore/innovate other perspectives, such as the possibility of a hybrid model.

Following, the suggested questions for the case:

Question 1. The case shows that Chianca went through a process of working arrangements for implementation of home office modality. With it in mind, describe this process narrated in the case, critically evaluating it.

One option to address this question is the teacher, based on Haubrich and Froehlich (2020), conduct the discussion by preparing a table with steps to implement the home office and encourage students to identify how was the implementation process of Chianca associated with literature. The Table 1 shows examples of analysis, not exhausting the possibilities that the teacher and students can work with during the discussions.

Finally, the student must reflect and critically evaluate the implementation process of the Chianca home office described, indicating whether they consider them satisfactory, or if something should change. It is expected that the closing of the question is a reflective exercise, so that students not only analytically indicate what was done by the company, but also, by assuming an analyst position, reflect on the decision-making.

Question 2. From the implementation of the home office in the context of Chianca, identify what were the benefits and challenges experienced by employees and by the company.

In order to solve this question, the teacher can conduct a discussion using the blackboard to draw a table, which should be filled with the benefits and the challenges of home office perceived in the case, and based on the literature (Brik \& Brik, 2013; Filardi \& Castro, 2017; Haubrich \& Froehlich, 2020; Hau \& Todescat, 2018). Thus, here are some suggestions for possible notes, as shown in Table 2.

Table 2 is exemplary and not restrictive, so the teacher and students, during the discussions, may perceive other factors. The teacher can also encourage students to reflect, based on the literature, on other benefits and challenges that Chianca may have faced, which are not described in the case. 
Table 1. Home office implementation.

Steps to implement

Step 1 - Start with flexibility issues

Step 2 - Choose flexible time and remote work centers

Step 3 - Establish short- and long-term participation goals

Step 4 - Choose an individual or group to direct the program

Step 5 - Set a budget and funding for flexible work

Step 6 - Establish home office work policies and agreements

Step 7 - Manage and get employees involved

Step 8 - Train managers, supervisors, and employees

Step 9 - Solve problems as they arise

Step 10 - Evaluate the results
Steps to implement the home office in Chianca

Initially, Chianca elaborated the plan for home office modality out of necessity. Thus, the process was adapted over time with the support of the Personnel and Management department to define how it would happen. Due to the pandemic, all employees were part of the new modality.

The office hours remained the same. The home of the employees became the remote work centers.

As it was implemented on an emergency basis, no closing time for the home office period was established due to the uncertainty of the pandemic.

Chianca had the direction of the head of Personnel and Management, and the heads of departments were responsible for implementing and monitoring the new arrangements and reporting the problems that could arise.

No budget was set for implementation. The company made equipment such as notebook, headset, and chair available for employees who did not have it at home, that is, it provided physical support.

The company created a home office conduct manual, establishing the rules for how employees must behave during working hours and which tools to use.

Due to the need to implement, the leaders were involved in applying the system and, then, adapted some integration practices in this new format.

The company did not have time to train leaders for implementation due to the urgent need for changes.

Some problems arose with equipment control and productivity during the im-plementation, for example, and the instruction of the company was that the leaders should report the difficulties to management department and solve them as they arise.

The performance of the teams was evaluated daily through meetings at the beginning and at the close of the day and through reports of the targets control.

Note. Source: Produced by the authors based on Haubrich and Froehlich (2020).

Table 2. Benefits and challenges for the employee and for the company.

\begin{tabular}{|c|c|c|}
\hline & Benefits & Challenges \\
\hline 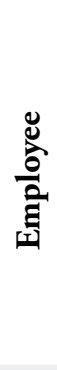 & $\begin{array}{l}\text { - Reduction of commute costs; } \\
\text { - Less exposure to traffic; } \\
\text { - Presence in raising and educating children; } \\
\text { - Autonomy for employees; } \\
\text { - Reduction of risk of infection by coronavirus; } \\
\text { - Productivity; } \\
\text { - Creation of new ways of standardized work. }\end{array}$ & $\begin{array}{l}\text {-Problem with physical, technological, and controlling infrastructure; } \\
\text { - Domestic demands; } \\
\text { - Absence of leadership and of sense of belonging to the culture; } \\
\text { - Lack of integration and of engagement; } \\
\text { - Organizational isolation; } \\
\text { - Differences in the traditional vs. home office worker relationship; } \\
\text { - Higher workload due to increased productivity; } \\
\text { - Difficulty in concentration; } \\
\text { - Tiredness due to the longer time in front of the screen. }\end{array}$ \\
\hline & $\begin{array}{l}\text { - Productivity; } \\
\text { - Reduction of absenteeism; } \\
\text { - Adaptation of customer services; } \\
\text { - Moral and job satisfaction; } \\
\text { - Retention and recruitment; } \\
\text { - Employee safety; } \\
\text { - Creation of flexible ways of working; } \\
\text { - Company's technological evolution due to the systematic use of new } \\
\text { information and telecommunication technologies; } \\
\text { - Increased virtual presence on social media; } \\
\text { - Less public transport charges; } \\
\text { - Emergence of new activities based on the intensive use of new emerging } \\
\text { technologies; } \\
\text { - Cost savings; } \\
\text { - Decrease in turnover. }\end{array}$ & $\begin{array}{l}\text { - Coordination and availability of workers; } \\
\text { - Difficulty of supervision and verification of results; } \\
\text { - Increasing in communication costs; } \\
\text { - Possibility of social and professional isolation; } \\
\text { - Loss of feeling of bond with the professional group and the employer; } \\
\text { - Possibilities of negative impacts on professional advancement and } \\
\text { adequate training; } \\
\text { - Technological incompatibility; } \\
\text { - Loss of sensitive data; } \\
\text { - Constant change in legislation; } \\
\text { - Vulnerability of data and resources. }\end{array}$ \\
\hline
\end{tabular}

Note. Source: Produced by the authors based on Haubrich and Froehlich (2020). 
Question 3. Among the challenges resulting from the implementation of home office modality, the lack of integration and engagement among employees were the most evident in the case. So, analyze what Chianca did and what it could have done to minimize them.

The answer for this question can be initially conducted by the teacher using the blackboard, so that, along with the students, he can raise the actions taken by Chianca to minimize the challenge of lack of engagement and the integration of employees. Thus, the students can emphasize the integration and practices of engagement that Chianca adapted from in-person work modality to the virtual one, namely: Birthday Boy/Girl of the Month, Gratitude Day, Happy Hour, Chianca Fit, and Day C.

Then the teacher should conduct the discussion provoking reflections about what Chianca could have done to minimize the challenges of social isolation by the home office. Thus, alternatives are suggested based on authors that analyzed this subject (Belzunegui-Eraso \& Erro-Garcés, 2020; Benjamim, 2020; Even, 2020), such as: provide means to face-to-face interactions, inclusion of employees in information exchange, and specialized training of leaders. However, despite the theoretical indications, it is important to note that the teacher has the autonomy to look for support from other sources in the literature.

In addition, the teacher can encourage the class through the brainstorm technique by proposing other practices of engagement of employees in home office modality. The technique consists of allowing all students the opportunity to present some idea without judgment, and, in the end, they can reflect on the suggestions. In addition, it may be asked to students to do research on websites, newspapers, and magazines to answer with examples how other companies managed to overcome the implementation challenges of the home office.

Question 4. From the reflections made on the home office implementation process, its benefits and challenges, if you were in the position of manager of Chianca Softwares, how would you decide between the dilemmas: Would you remain on the remote work modality or return to in-person work modality? Are there other possibilities? Justify your decision.

This question culminates in the decision-making of students in the role of managers of Chianca Softwares before two alternatives: (a) Continue at home office; or (b) Return to in-person work. Thus, the teacher can divide the class into small groups according to the chosen position, and then propose to present the justification for the decisionmaking based on the case, taking into account the benefits and challenges identified in previous questions.
The teacher can start the discussion with the team that wants to continue in the home office modality and request that they present arguments for the decision:

(a) To continue in the office home modality: Chianca managed to structure all of its business to the new format in a short period, showing adaptability in times of crisis. The employees have the structure to work at home and the work plans have been adapted. Employees can spend more time with their families, in addition to reducing transportation costs and commuting time, which are presented as the main benefits of this modality.

While the group opting for the home office scheme is raising the factors inherent in the permanence of this model, the teacher can highlight them on the blackboard, and, therefore, ask the other group to submit the justification for the traditional system:

(b) Return to in-person work: The company invested in physical space with thematic rooms, meeting rooms, lounge, games room, installed solar panel, and the entire business structure is underused. The difficulties faced during this period (such as controlling employee productivity, communicating with the leadership, and implementation of team integration and engagement practices), although ongoing, cannot be compared to in-person contact. Direct contact with the customer is also extremely important, despite the evolution of technology, for the relationship with people remains the key point for business.

(c) A third group may also be formed, consisting of students showing a third alternative: the hybrid work modality. This, in turn, has gained prominence for combining the advantages of he previously described modalities: in-person and home office. The study by Benjamim (2020) reveals that there are a number of virtual workers who prefer the hybrid model, that is, to work part of the time in the workplace of the company and another in home office. A hybrid work model can be a great transition for companies considering remote work options.

According to Benjamim (2020), what hinders or prevents the implementation of this model is the lack of knowledge of organizations and the need for control, which generates distrust in the work environment. Thus, the teacher can use the implementation model of this hybrid alternative (Benjamim, 2020), as shown in Figure 1, leading students to a reflection and discussion to solve the dilemma. 


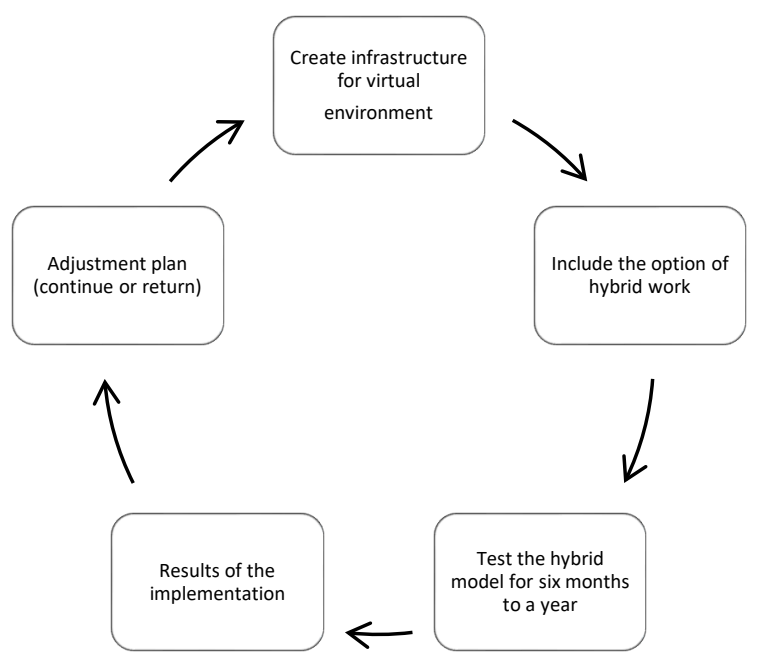

Figure 1. Hybrid model implementation process. Source: Produced by the authors based on Benjamim (2020).

Finally, at the end of the discussions, it is expected that students can reflect on the various aspects that guide the home office modality, its benefits and challenges, and that they can analyze perspectives for decision-making in times of crisis, creating innovative mechanisms, thinking about the different ways to stay in the job market with the use of technology without forgetting to engage people during the process.

\section{TEACHING PROCESS}

To work the case, it is recommended that the teacher follow three steps: planning, application, and evaluation. The planning stage is to review the case and identify possible topics to be discussed in classroom that can coincide with the theme proposed in these notes, or the teacher can create and adapt other issues, taking into account the time available for the execution of the case.

The teacher must send the case to the students at least 15 days in advance, and they are supposed to go to the discussion class with the questions answered individually and deliver them to the teacher before the discussion. Then, the moderator conducts the debate observing the order of the issues that start from the company's diagnosis, the home office implementation process, the benefits and challenges of the implementation, and the mechanisms for mitigating the challenges of the home office model. Then, there is the application of the case in a two-hour class:

(a) Initially, the teacher may ask if students know any company that made the change to home office modality in order to warm up the debate. After this warm-up on the subject, the teacher can move on to the first question, asking students to report their answers individually, writing on the blackboard how Chianca implementation process occurred in light of the theory (20 minutes).

(b) Then, the teacher can ask about the second question, what benefits and challenges the implementation of the home office brought to Chianca and employees, drawing at this time on the blackboard a $2 \times 2$ matrix, as shown in the analysis of the case, encouraging debate with all participants (30 minutes).

(c) In this option, the teacher can divide the students into small groups to discuss about the mitigation of the challenges of home office more deeply, with the students having their individual responses and researches carried out on sites and newspapers about other companies. This format allows participants to feel more comfortable to debate and argue among themselves, and the teacher can encourage discussions with questions and notes from the case, as suggested in the third question. In this first moment, the teacher can make clear that students need to write a technical report of what was discussed in groups on the third question, particularly about what Chianca did not do and could have done to mitigate the challenges in home office (40 minutes).

(d) For last question, in small groups, students should discuss about what they would do in place of the directors of Chianca: stay at home office modality or return to the in-person model of work. Students need to come to a consensus among the groups, and then the teacher can resume the debate with all participants, writing the vote on the blackboard, as well as the main arguments for the decisions of the groups. At the end, the teacher can present the third possibility of hybrid model in light of the literature (30 minutes). 
The criteria of evaluation can be: (a) individual writing task, (b) technical report (in-group), and (c) participation in the final decision, and the teacher can assign different grades for each activity.
The use of teaching cases gives students the opportunity to apply theoretical concepts to practical situations. The teacher should conduct and monitor the process by intervening with questions and encouraging the participation of students, while also assessing the skills being developed in the classroom.

\section{REFERENCES}

Belzunegui-Eraso, A., \& Erro-Garcés, A. (2020). Teleworking in the context of the Covid-19 crisis. Sustainability, 12(9), 3662. https://doi.org/10.3390/su12093662

Benjamin, L. (2020). Achieving the dream through a screen: Exploring employeeengagementandcommitmentinvirtualenvironments (Master Thesis). University of Pennsylvania, USA. Retrieved from https://repository.upenn.edu/od theses $\mathrm{msod} / 103$

Brik, M. S., \& Brik, A. (2013). Trabalho portátil: Produtividade, economia e qualidade de vida no home office das empresas. Curitiba, PR: Authors' Edition.

Even, A. (2020). The evolution of work: Best practices for avoiding social and organizational isolation in telework employees. SSRN. https://doi.org/10.2139/ssrn.3543122
Filardi, F., \& Castro, R. M. P. de (2017). Análise dos resultados da implantaçáo do teletrabalho na administraçáo pública: Estudo dos casos do SERPRO e da Receita Federal. Anais do Encontro da Associação Nacional de Pós-Graduação e Pesquisa em Administração, São Paulo, SP, Brasil, 41.

Haubrich, D. B., \& Froehlich, C. (2020). Benefícios e desafios do home office em empresas de tecnologia da informaçáo. Revista Gestão \& Conexóes, 9(1), 167-184. https://doi. org/10.13071/regec.2317-5087.2020.9.1.27901.167-184

Hau, F., \& Todescat, M. (2018). O teletrabalho na percepçáo dos teletrabalhadores e seus gestores: Vantagens e desvantagens em um estudo de caso. Revista de Gestäo e Tecnologia, 8(3), 37-52. https://doi.org/10.22279/navus.2018.v8n3.p37-52.601 


\section{Authorship}

\section{Thaís Lopes de Lucena Alves*}

Universidade Federal da Paraíba, Centro de Ciências Sociais Aplicadas, Programa de Pós-Graduação em Administração

Campus I Universidade Federal da Paraíba, Via Expressa Padre Zé, no 289, Castelo Branco III, 58051-900, João Pessoa, PB, Brazil

E-mail address: thaislopessa@gmail.com

(1) https://orcid.org/0000-0002-3183-2569

\section{Amanda Florense Alves Amorim}

Universidade Federal da Paraíba, Centro de Ciências Sociais Aplicadas, Programa de Pós-Graduação em Administração

Campus I Universidade Federal da Paraíba, Via Expressa Padre Zé, no 289, Castelo Branco III, 58051-900, João Pessoa, PB, Brazil

E-mail address: amandaamorimufpb@gmail.com

(1) https://orcid.org/0000-0003-0445-5179

\section{Maria Clara Cunha Bezerra}

Universidade Federal da Paraíba, Centro de Ciências Sociais Aplicadas, Programa de Pós-Graduação em Administração

Campus I Universidade Federal da Paraíba, Via Expressa Padre Zé, no 289, Castelo Branco III, 58051-900, João Pessoa, PB, Brazil

E-mail address: mariaclarabezerraa@hotmail.com

(1) https://orcid.org/0000-0002-0399-1335

* Corresponding Author

\section{Funding}

The authors reported that there is no financial support for the research in this article.

\section{Conflict of Interests}

The authors have stated that there is no conflict of interest.

\section{Peer Review Method}

This content was evaluated using the double-blind peer review process. The disclosure of the reviewers' information on the first page, as well as the Peer Review Report, is made only after concluding the evaluation process, and with the voluntary consent of the respective reviewers and authors.

\section{Authors' Contributions}

$1^{\text {st }}$ author: conceptualization (lead); data curation (lead); formal analysis (lead); investigation (lead); methodology (lead); project administration (lead); resources (lead); validation (lead); visualization (lead); writing-original draft (lead); writing-review \& editing (lead).

$2^{\text {nd }}$ author: conceptualization (equal); formal analysis (equal); investigation (equal); methodology (equal); project administration (supporting); resources (supporting); validation (supporting); visualization (supporting); writingoriginal draft (equal); writing-review \& editing (equal).

$3^{\text {rd }}$ author: conceptualization (equal); formal analysis (equal); investigation (equal); methodology (equal); resources (equal); validation (equal); writing-original draft (supporting); writing-review $\&$ editing (supporting).

\section{Copyrights}

RAC owns the copyright to this content.

\section{Plagiarism Check}

The RAC maintains the practice of submitting all documents approved for publication to the plagiarism check, using specific tools, e.g.: iThenticate.

\section{Data Availability}

All data and materials have been made publicly available through the Harvard Dataverse platform and can be accessed at:

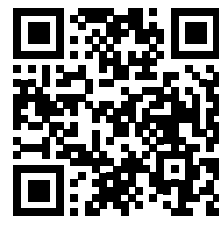

Thaís Lopes de Lucena Alves; Amanda Florense Alves Amorim; Maria Clara Cunha Bezerra, 2021, "Replication Data for: "Not one less"! Adaptation to the home office in times of Covid-19.", Harvard Dataverse, V1. https://doi.org/10.7910/DVN/NN5FXM

RAC encourages data sharing but, in compliance with ethical principles, it does not demand the disclosure of any means of identifying research subjects, preserving the privacy of research subjects. The practice of open data is to enable the reproducibility of results, and to ensure the unrestricted transparency of the results of the published research, without requiring the identity of research subjects. 